\title{
Analisis Perbandingan Pengaruh Pembiayaan Murabahah Terhadap Laba Bank Mega Syariah Distrik Tangerang Tahun 2015
}

\author{
Oleh: \\ Sunardi \\ Kartika Indah
}
Sekolah Tinggi Ekonomi Syariah (STES) Islamic Village Tangerang Jl. Islamic Raya Kelapa Dua Tangerang-Banten

\begin{abstract}
Abstrak: Tujuan dari penelitian ini adalah untuk menguji perbandingan pengaruh pembiayaan murabahah terhadap laba Bank Mega Syariah Distrik Tangerang dengan menggunakan rasio Return On Asset (ROA). Metode yang digunakan dalam penelitian ini adalah metode deskriptif kuantitatif, jenis data yang diperoleh merupakan data sekunder yang berdasarkan dari hasil laporan keuangan perbulan 5 (lima) kantor cabang pembantu tahun 2015 yaitu Bank Mega Syariah Kantor Cabang Pembantu Curug, Bank Mega Syariah Kantor Cabang Pembantu Pasar Kemis, Bank Mega Syariah Kantor Cabang Pembantu Sukarasa, Bank Mega Syariah Kantor Cabang Pembantu Tangerang City dan Bank Mega Syariah Kantor Cabang Pembantu Modern BSD. Pengujian statistik yang digunakan adalah model regresi sederhana dan uji hipotesis. Hasil penelitian menunjukkan bahwa pembiayaan murabahah tidak memberikan pengaruh langsung positif terhadap ROA (return on asset).
\end{abstract}

Kata Kunci: Perbankan Syariah, Pembiayaan Murabahah, Laba

\section{Pendahuluan}

Pembiayaan merupakan aktiva produktif dari perbankan syariah, yang harus dikelola dengan memperhatikan prinsip kehati-hatian, berdasarkan pada peraturan-peraturan yang membatasinya, analisa terhadap risiko usaha, transparansi dalam oprasional bank syariah yang mempertahankan kepercayaan masyarakat dan investor kepada perbankan syariah.

Dalam operasional perbankan syariah, besar kecilnya sebuah risiko yang terjadi juga sangat ditentukan oleh kecermatan perencanaan arus kas berdasarkan prediksi pembiayaan dan prediksi pertumbuhan dana, ketetapan dalam mengatur struktur dana, ketersediaan aset yang siap 
dikonversikan menjadi kas dan kemampuan menciptakan akses pasar antara bank dan sumber dana lainnya.

Menurut Osmad (2012:21) masalah yang dihadapi oleh perbankan syariah adalah standarisasi sistem akuntansi dan audit, yang bertujuan untuk menciptakan transparansi keuangan sekaligus memperbaiki kualitas pelayanan keuangan kepada masyarakat. Oleh karena itu membangun sebuah sistem akuntansi dan audit yang bersifat standar telah menjadi kebutuhan utama yang harus dipenuhi, menyangkut pengakuan, pengukuran, penyajian, dan pengungkapan dalam sistem akuntansi.

Kemampuan memperoleh laba adalah suatu ukuran dalam persentase yang digunakan untuk menilai sejauh mana perusahaan mampu menghasilkan laba pada tingkat yang dapat diterima karena itu adalah ukuran bagi kesehatan perusahaan. Salah satu penyebab menurunnya laba bank adalah karena adanya penurunan dalam perolehan pendapatan yang lebih kecil dibandingkan dengan beban yang terjadi. Sehingga untuk meningkatkan kembali laba yaitu dengan cara meningkatkan pendapatan dan meminimalkan beban.

Adapun yang terjadi pada kondisi penurunan laba karena tidak terlepas dari risiko terjadinya pembiayaan bermasalah atau NPF (non performing finance) merupakan salah satu indikator kunci untuk menilai kinerja fungsi bank. Pendapatan bank syariah sangat ditentukan oleh berapa banyak laba yang diterima dari pembiayaan yang disalurkan. Dengan diperolehnya pendapatan dari pembiayaan yang disalurkan diharapkan profitabilitas bank syariah akan membaik, tercermin dari perolehan laba yang meningkat. Pembiayaan murabahah dalam jumlah besar dapat membawa hasil yang menguntungkan bagi pihak bank syariah. Jika penyaluran pembiayaan tersebut dalam pengembaliannya berjalan dengan lancar.

\section{Metode}

Dalam penelitian ini metode yang digunakan adalah metode deskriptif kuantitatif yang berupa data sekunder yaitu laporan keuangan perbulan Bank Mega Syariah Kantor Cabang Pembantu Curug, Bank Mega Syariah Kantor Cabang Pembantu Pasar Kemis, Bank Mega Syariah Kantor Cabang Pembantu Sukarasa, Bank Mega Syariah Kantor Cabang Pembantu Tangerang City dan Bank Mega Syariah Kantor Cabang Pembantu Modern BSD Tahun 2015. Dengan asumsi bahwa aset yang digunakan hanya dari total piutang murabahah, karena kelima kantor cabang pembantu yang diteliti tidak terlihat total aset, sementara yang ada aset pembiayaan yang mana jenis pembiayaan hanya piutang murabahah. 
Metode Pengumpulan Data

Teknik pengumpulan data yang digunakan adalah metode dokumentasi, meliputi engumpulan data sekunder yang berupa laporan keuangan perbulan tahun 2015 Bank Mega Syariah Distrik Tangerang yang diperoleh langsung dari Bank Mega Syariah.

Populasi

Popolasi dalam penelitian ini adalah data laporan keuangan perbulan tahun 2015 Bank Mega Syariah Distrik Tangerang, dari lima kantor cabang pembantu yaitu Bank Mega Syariah Kantor Cabang Pembantu Curug, Bank Mega Syariah Kantor Cabang Pembantu Pasar Kemis, Bank Mega Syariah Kantor Cabang Pembantu Sukarasa, Bank Mega Syariah Kantor Cabang Pembantu Tangerang City dan Bank Mega Syariah Kantor Cabang Pembantu Modern BSD.

Operasional Variabel

1. Variabel Independen (X)

Merupakan variabel yang mempengaruhi atau yang menjadi sebab perubahannya atau timbulnya variabel dependen (terkait). Dalam penelitian ini yang menjadi variabel independen $(\mathrm{X})$ adalah pembiayaan murabahah.

Murabahah dalam aplikasi bank syariah adalah bank merupakan penjual atas objek barang dan nasabah merupakan pembeli. Bank menyediakan barang yang dibutuhkan oleh nasabah dengan membeli barang dari supplier, kemudian menjualnya kepada nasabah dengan harga yang lebih tinggi. Pembayaran atas transaksi murabahah dapat dilakukan dengan cara membayar sekaligus pada jatuh tempo atau melakukan pembayaran angsuran selama jangka waktu yang disepakati.

2. Variabel Dependen (Y)

Merupakan variabel yang dipengaruhi atau yang menjadi akibat, karena adanya variabel bebas. Dalam penelitian ini yang menjadi variabel dependen (Y) adalah laba sebelum pajak dari pendapatan perbulan pembiayaan murabahah menggunakan rasio keuangan ROA (return on asset) tahun 2015.

a. Laba adalah selisih pendapatan dan keuntungan setelah dikurangi beban dan kerugian.

b. Return on asset adalah perbandingan antara pendapatan bersih (net income) dengan rata-rata aktiva (average assets) atau perbandingan dari laba sebelum pajak terhadap total asset. 
Teknik Analisis Data

1. Uji Asumsi Klasik

Digunakan untuk menghindari munculnya bias dalam analisis data serta untuk menghindari kesalahan spesifikasi model regresi yang digunakan.

2. Uji Regresi Sederhana

Teknik analisis regresi yang menganalisis model secara sederhana dengan menggunakan satu variabel independen dan satu variabel dependen.

3. Uji Hipotesis

Pengujian hipotesis dilakukan untuk menguji hipotesis penelitian secara simultan dan parsial dengan tujuan membandingkan hipotesis yang diajukan, antara lain:

a. Uji statistik parsial (uji statistik t)

Uji t pada dasarnya menunjukan dan seberapa jauh pengaruh suatu variabel penjelas secara individual dalam menerangkan variabel terkait.

b. Uji signifikansi simultan (uji statistik F)

Uji $\mathrm{F}$ digunakan untuk menguji variabel-variabel bebas secara bersamaan terhadap variabel terkait. Selain itu dengan uji $\mathrm{F}$ ini dapat diketahui pula apakah model regresi linier yang digunakan sudah tepat atau belum.

\section{Hasil}

Berdasarkan perhitungan dapat diketahui bahwa dari total pembiayaan murabahah lima kantor cabang pembantu yang memiliki rasio laba terendah sebesar $0,014 \%$ dengan tingkat NPF (non performing finance) cukup tinggi sebesar 1,64\% dimiliki oleh Bank Mega Syariah Kantor Cabang Pembantu Curug dan rasio laba tertinggi sebesar 0,304\% dengan tingkat NPF (non performing finance) terendah sebesar 0,008\% dimiliki oleh Bank Mega Syariah Kantor Cabang Pembantu Tangerang City.

\section{Uji Asumsi Klasik}

Berdasarkan Normal probability plot of residual, diketahui bahwa residual menyerupai suatu plot garis lurus, sehingga dapat disimpulkan bahwa residual berdistribusi normal.

Berdasarkan Normal Histogram, terlihat bahwa sebaran data residual secara umum menyerupai bentuk lonceng, sehingga dapat disimpulkan bahwa residual berdistribusi normal. 


\section{Analisis Regresi Sederhana}

Ketika tidak ada tambahan dari pembiayaan murabahah maka ROA (return on asset) sebesar 0,764 satuan, dan apabila adanya tambahan dari pembiayaan murabahah sebesar 1 (satuan) maka ROA (return on asset) bertambah 0,001 satuan.

\section{Pengujian Hipotesis}

- Berdasarkan pada hasil uji regresi, ditunjukkan bahwa pengujian variabel murabahah terhadap ROA (return on asset) menghasilkan nilai thitung sebesar 0,821 dengan ttabel sebesar $1,671(0,821<1,671)$ dan dengan tingkat signifikansi 0,415. Oleh karena nilai signifikan $>\alpha=0,05$ maka dapat disimpulkan bahwa $\mathrm{Ho}$ diterima dan $\mathrm{Ha}_{\mathrm{a}}$ ditolak. Yang artinya pembiayaan murabahah tidak berpengaruh signifikan terhadap ROA (return on asset).

Berdasarkan hasil analisis, diketahui hasil uji $\mathrm{F}$ untuk variabel pembiayaan murabahah sebesar 0,674 dengan Ftabel sebesar 4,00 $(0,674<4,00)$ dan dengan tingkat signifikansi 0,415. Asumsi dalam uji F adalah Fhitung $>$ Ftabel dan tingkat signifikan $<\alpha=0,05$. Dengan demikian hal tersebut menunjukkan bahwa $\mathrm{H}_{0}$ diterima dan $\mathrm{Ha}$ ditolak. Secara simultan menunjukkan bahwa variabel independen yaitu pembiayaan murabahah tidak berpengaruh terhadap variabel dependen yaitu laba sebelum pajak dalam rasio ROA (return on asset). Dengan nilai koefisien determinasi $\left(\mathrm{R}^{2}\right)$ sebesar 0,011 artinya variabel pembiayaan murabahah mempengaruhi laba distrik Tangerang sebesar 1,1\%. Sedangkan sisanya 98,9\% adalah variabel independen lain yang tidak diteliti dalam penelitian ini.

\section{Pembahasan}

Dari sampel yang diteliti untuk periode tahun 2015 dari total pembiayaan murabahah lima kantor cabang pembantu yang memiliki rasio laba terendah sebesar 0,014\% dengan tingkat NPF (non performing finance) cukup tinggi sebesar 1,64\% dimiliki oleh Bank Mega Syariah Kantor Cabang Pembantu Curug, bahwa Bank Mega Syariah Kantor Cabang Pembantu Curug harus memperhatikan penyaluran - pembiayaannya agar bisa menurunkan NPF (non performing finance) karena akan berpengaruh pada kinerja keuangan perusahaan sehingga bank dianggap tidak sehat. Dan rasio laba tertinggi sebesar 0,304\% dengan tingkat NPF (non performing finance) terendah sebesar 0,008\% dimiliki oleh Bank Mega Syariah Kantor Cabang Pembantu Tangerang 
City. Bahwa Bank Mega Syariah Kantor Cabang Pembantu Tangerang City mampu mempergunakan asetnya secara efisien dan juga memberikan ukuran yang lebih baik atas kinerja perusahaan karena menunjukkan efektifitas manajemen sehingga mampu menghasilkan laba lebih besar terhadap distrik Tangerang.

Hasil uji regresi membuktikan bahwa terdapat pengaruh kurang signifikan antara variabel pembiayaan murabahah (X) terhadap ROA (return on asset) (Y) sebesar 0,001 artinya ketika tidak ada tambahan dari pembiayaan murabahah maka ROA (return on asset) sebesar 0,764 satuan, dan apabila adanya tambahan dari pembiayaan murabahah sebesar 1 (satuan) maka ROA (return on asset) bertambah 0,001 satuan, dengan demikian hubungan antara pembiayaan murabahah dengan ROA (return on asset) negatif. Karena dalam pembiayaan murabahah adanya penurunan kewajiban, setiap bulan nasabah akan membayar kewajibannya kepada bank sampai lunas sehingga kewajiban murabahah nasabah akan menurun setiap bulannya sehingga tidak memiliki kewajiban lagi. Dalam pembiayaan murabahah juga terdapat percepatan pelunasan, nasabah ingin langsung melunasi seluruh kewajibannya kepada bank. Sehingga keuntungan yang seharusnya akan masuk tetapi hilang karena adanya percepatan pelunasan yang juga akan mengurangi aset sehingga ROA (return on asset) juga menurun. Selain itu terdapat pembiayaan bermasalah yang berakibat pada kerugian bank, karena tidak diterimanya kembali dana yang telah disalurkan maupun keuntungan yang tidak dapat diterima sehingga berakibat pada penurunan pendapatan perusahaan.

Penelitian ini sejalan dengan hasil penelitian yang dilakukan oleh Amri Dziki Fadholi (2015) yang meneliti mengenai Pengaruh Pembiyaan Murabahah, Musyarakah dan Mudharabah Terhadap Profitabilitas Bank Umum Syariah periode 2011-2014. Dengan hasil pengujian statistik uji t dijelaskan sebagai berikut. 1) Pengaruh pembiayaan murabahah terhadap profitabilitas Bank Umum Syariah. Berdasarkan pengujian variabel murabahah terhadap ROA menghasilakan nilai statistik t sebesar $-0,770$ dengan tingkat signifikansi (probabilitas) $=0,444$ lebih besar dari 0,05 $(0,444>0,05)$. Oleh karena nilai probabilitas $>\alpha(5 \%)$ maka dengan demikian bahwa murabahah tidak berpengaruh terhadap ROA (return on asset). Hasil ini tidak sesuai dengan hipotesis. 2) Reinissa R (2015) yang meneliti mengenai Pengaruh Pembiayaan Mudharabah, Musyarakah, dan Murabahah Terhadap Profitabilitas Bank Syariah Mandiri, TBK periode 2009-2012. Dengan hasil statistik uji t dijelaskan sebagai berikut. Uji parsial pada model regresi 1 variabel murabahah menunjukkan nilai signifikan sebesar 0,0524. Jika menggunakan $\alpha 5 \%$ maka hasilnya akan 
tidak berpengaruh signifikan namun jika menggunakkan $\alpha 10 \%$ maka variabel murabahah berpengaruh signifikan dan negatif terhadap ROA (return on asset).

Achmad Nurdany (2012) yang meneliti mengenai Analisis Pengaruh Rasio Keuangan Rentabilitas Terhadap Pendapatan Margin Murabahah Bank Syariah. Dengan hasil hipotesis dijelaskan sebagai berikut. Probabilitas variabel ROA sebesar 0,000 dimana angka tersebut lebih kecil dari 0,05 (signifikan 5\%) akan tetapi arah pengaruhnya negatif, dilihat dari koefisien ROA yang menunjukkan angka -2,235. Sehingga ROA berpengaruh signifikan dan negatif terhadap pembiayaan murabahah.

Agung Yulianto (2014) yang meneliti mengenai Pengaruh Pembiayaan Bagi Hasil, Pembiayaan Jual Beli, Financing To Deposit Ratio (FDR) Dan Non Performing Finance (NPF) Terhadap Profitabilitas Bank Umum Syariah di Indonesia. Dengan hasil pengujian statistik uji $t$ dijelaskan sebagai berikut. Uji thitung sebesar 0,687 dengan signifikansi sebesar 0,496, menunjukkan nilai diatas tingkat signifikan sebesar 5\% ( $\alpha$ $=0,05$ ) yang artinya bahwa secara parsial pembiayaan jual beli tidak berpengaruh terhadap ROA.

Mirasanti Wahyuni (2016) yang meneliti mengenai Pengaruh Volume Pembiayaan Bagi Hasil dan Pembiayaan Murabahah Terhadap Kinerja Keuangan Bank Umum Syariah Dengan NPF Sebagai Variabel Moderasi. Dengan hasil pengujian statistik uji t dijelaskan sebagai berikut. Hasil penelitian ini menunjukan bahwa uji thitung -2,711 lebih kecil dari nilai ttabel 2,026 dengan nilai signifikan 0,010 artinya pembiayaan murabahah mempunyai pengaruh yang negatif terhadap kinerja bank umum syariah.

\section{Simpulan}

Berdasarkan dari hasil penelitian dan pembahasan maka dapat diambil kesimpulan bahwa pembiayaan murabahah secara parsial dan simultan tidak berpengaruh terhadap ROA (return on asset) Bank Mega Syariah Distrik Tangerang. Hal ini dapat diartikan bahwa bank sebaiknya lebih meningkatkan prinsip dasar dalam pemberian pembiayaan serta analisis yang mendalam terhadap calon nasabah, agar bank tidak salah memilih dalam penyaluran dananya sehingga dana yang disalurkan kepada nasabah dapat terbayar kembali sesuai jangka waktu yang diperjanjikan. Lebih meningkatkan pengawasan kepada nasabah yang melakukan pembiayaan bermasalah yang dapat menyebabkan terjadinya kemacetan dalam pengembalian pembiayaan, sehingga keuntungan yang diperoleh dapat maksimal dan juga memperoleh laba yang optimal. Dan lebih meningkatkan pemasaran, memilih strategi inovasi yang tepat untuk 
penjualan produk-produk yang ditawarkan. Untuk penelitian selanjutnya diharapkan dapat menambahkan variabel baru yang berkaitan dengan laba selain pembiayaan murabahah dan menggunakan tahun penelitian yang lebih panjang.

\section{Daftar Pustaka}

Antonio, Muhammad Syafii, Bank Syariah Dari Teori Ke Praktek, Jakarta: Gema Insani, 2016

Fadhila, Novi, Analisis Pembiayaan Mudharabah dan Murabahah Terhadap Laba Bank Syariah Mandiri, Vol. 15 No. 1 (Maret 2015) H. 65-77

Fadholi, Amri Dziki, Pengaruh Pembiayaan Murabahah, Musyarakah, dan Mudharabah Terhadap Profitabilitas Bank Umum Syariah, Jurnal Penelitian: 2015

Fauziah, Nurul, Seberapa Besar Pengaruh Pembiayaan Musyarakah dan Pembiayaan Mudharabah Terhadap Laba Bersih Pada Bank Umum Syariah, 2014

Hery, Cara Mudah Memahami Akuntansi, Jakarta: Prenadamedia Group, 2012

Hery, Praktis Menyusun Laporan Keuangan, Jakarta: Grasindo, 2015

Ismail, Manajemen Perbankan Dari Teori Menuju Aplikasi, Jakarta: Prenadamedia Group, 2010

Ismail, Perbankan Syariah, Jakarta: Prenadamedia Group, 2011

Karim, Adiwarman, A., Bank Islam Analisis Fiqih dan Keuangan, Jakarta: PT RajaGrafindo Persada, 2014

Kartikahadi, Hans, dkk, Akuntansi Keuangan Berdasarkan SAK Berbasis IFRS, Jakarta: Salemba Empat, 2012

Muthaher, Osmad, Akuntansi Perbankan Syariah, Yogyakarta: Graha Ilmu, 2012

Nurdany, Achmad, Analisis Pengaruh Rasio Keuangan Rentabilitas Terhadap Pendapatan Margin Murabahah Bank Syariah, Vol. 5 No. 2 (Januari 2012) H. 14-24

Prawironegoro, Darsono, Akuntansi Manajemen, Jakarta: Diadit Media, 2005

Reinissa, Pengaruh Pembiayaan, Mudharabah, Musyarakah, dan Murabahah Terhadap Profitabilitas Bank Syariah Mandiri, Jurnal Penelitian: 2015

Sadi, Muhamad, Konsep Hukum Perbankan Syariah, Malang: Setara Press, 2015

Sjahdeini, Sutan Remy, Perbankan Syariah Produk-Produk dan AspekAspek Hukumnya, Jakarta: Prenadamedia Group, 2014 
Sugiono, Arief, dan Edi Untung, Analisa Laporan Keuangan, Jakarta: Grasindo, 2016

Sugiyono, Metode Penelitian Kombinasi, Bandung: Alfabeta, 2015

Sumar'in, Konsep Kelembagaan Bank Syariah, Yogyakarta: Graha Ilmu, 2012

Supardi, Aplikasi Statistika Dalam Penelitian, Jakarta: Change Publication, 2013

Wahyuni, Mirasanti, Pengaruh Volume Pembiayaan Bagi Hasil Dan Pembiayaan Murabahah Terhadap Kinerja Keuangan Bank Umum Syariah Dengan NPF Sebagai Variabel Moderasi, Vol. 7 No. 1 (Juni 2016) H. 1-10

Yulianto, Agung, Pengaruh Pembiayaan Bagi Hasil, Pembiayaan Jual Beli, Financing To Deposit Ratio (FDR) Dan Non Performing Finance (NPF) Terhadap Profitabilitas Bank Umum Syariah Di Indonesia, ISSN 2252-6765 (November 2014) H. 466-474

Yuniar, Mega, Pengaruh Pembiayaan Akad Murabahah Terhadap Laba Bank Syariah yang Terdaftar di Bursa Efek Indonesia, 2014 